\title{
ETIKA KOMUNIKASI VISUAL: PENCARIAN KEBENARAN DALAM PEMAHAMAN ANTARA YANG DILIHAT DAN YANG DIPIKIRKAN
}

\section{VISUAL COMMUNICATION ETHICS: SEARCHING FOR THE TRUTH IN UNDERSTANDING BETWEEN WHAT IS SEEN AND THOUGHT}

\author{
St. Hardiyarso \\ Universitas Katolik Soegijapranata \\ Email: hardiyarso@unika.ac.id
}

\begin{abstract}
On an exchange of information, the rational concept of massage comes from the communicator. In order to arrive at the intended communicant, the message must be conveyed through communication media. Among the many media, visual media is known as a mediator messages such the most effective, relying on sense perception vision and reduced comprehension ratio The effectiveness of visual communication becomes evident, when communicants are able to capture and perceive the meaning of visual messages critically, rational and objective, in accordance with the original rational idea of the communicator. However, it is not uncommon for that factor third, the situation around the communicant and the communicator also influences the communication process visual. Consequently, there is no equivalent between rational perception, media and visual perception by communicant, which is commonly referred to as miscommunication. The impact of errors in understanding will of course determine behavior. Indeed, communication is held with a view to influence. In order to that the conditions do not occur to blame each other, or look for "scapegoats", a philosophical study of the dynamics of visual communication is deemed necessary to find out basic principles of visual communication. As a philosophical study, the method used is a systematic-speculative method which emphasizes rational reflexive thinking with support by an interpretative and comparative study are holistically philosophical. Through this method, the communication process visuals are compared with the process of seeking knowledge by philosophers, especially Plato and Aristotle. The results of the study indicate that the source of communication misunderstandings can come, both communicators, communicants and the third factor, the environment. These mistakes can be differentiated, whether intentional or not. Deliberate intended for profit; and accident occurs, because of errors in the way of thinking, for example, sense perception is understood as rational perception, and vice versa.
\end{abstract}

Keywords : perception of ratio, sense perception, ideas, form, material, misunderstanding-communication

\begin{abstract}
Abstrak
Dalam proses pertukaran informasi, komunikator adalah sumber dari adanya ide rasional untuk sebuah pesan. Supaya sampai pada pihak yang dituju, komunikan, pesan tersebut harus disampaikan melalui media-media komunikasi. Di antara sekian banyak media, media visual sebagai pengantar pesan sekarang dipandang sebagai yang paling efektif, karena mengandalkan pencerapan indera penglihatan dan mengurangi pemahaman rasio. Efektifitas komunikasi visual menjadi nyata, ketika komunikan mampu menangkap dan mencerap makna pesan visual secara kritis rasional dan objektif, sesuai dengan gagasan rasional asali dari komunikator. Akan tetapi, tidak jarang terjadi, bahwa faktor ketiga, situasi di sekitar
\end{abstract}


komunikan dan komunikator pun memberi pengaruh dalam proses komunikasi visual. Akibatnya, tidak ada kesepadanan antara persepsi rasional, media dan pencerapan visual oleh komunikan, yang biasa disebut sebagai miss-komunikasi. Dampak dari kesalahan dalam pemahaman tentunya akan menentukan perilaku. Memang, komunikasi diadakan dengan tujuan untuk mempengaruhi. Supaya tidak terjadi kondisi saling mempersalahkan, atau mencari "kambing hitam", pengkajian secara filosofis atas dinamika komunikasi visual dipandang perlu untuk menemukan prinsip-prinsip dasar komunikasi visual. Sebagai kajian filsafati, metode yang dipergunakan adalah metode sistematis-spekulatif yang menekankan cara berpikir refleksif rasional dengan dukungan metode interpretatif dan komparatif secara holistik filsafati. Melalui metode ini, proses komunikasi visual diperbandingkan dengan proses pencarian pengetahuan oleh para filsuf, terutama Plato dan Aristoteles. Hasil kajian menunjukkan bahwa sumber kesalahpahaman komunikasi dapat berasal, baik komunikator, komunikan maupun faktor ketiga, lingkungan. Kesalahan tersebut pun dapat dibedakan, apakah disengaja atau tidak. Kesengajaan dimaksudkan untuk mencari keuntungan; dan ketidaksengajaan terjadi, karena kesalahan dalam cara berpikir, misalnya persepsi inderawi dipahami sebagai persepsi rasional, dan sebaliknya.

Kata Kunci : persepsi rasio, persepsi inderawi, idea-idea, forma, materia, kesalahpemahaman-komunikasi

\section{PENDAHULUAN}

Komunikasi sebagai aktifitas sosial yang paling utama memang tidak mudah untuk diidentifikasi (Goldberg dan Larson, 2011:17-18). Komunikasi pun akan berdaya ubah pada identitas yang seperti apa yang akan membentuk diri, nilai-nilai apa yang dianut, menjadi tujuan dan diperjuangkan. Untuk itu, pengkajian secara sistematis akan dinamika komunikasi perlu dilakukan secara terus menerus. Peran sentral komunikasi dalam kehidupan manusia semakin disadari dan dirasakan, pada masa sekarang, ketika komunikasi tidak sebatas ucapan dari bibir yang didukung dengan gesture yang dilihat secara langsung, tetapi diwujudkan dengan pelbagai simbol dan tanda visual

Dalam pergaulan sosial, sering kali ditemukan pelbagai macam aktifitas manusia yang mengandung, menyampaikan makna dan sebaliknya, menangkap, mencerap makna sebagai lebih dari hal yang tampak oleh pancaindera. Sebagai misal, peribahasa-peribahasa, seperti: "air beriak tanda, tak dalam", "tidak ada asap, kalau tidak ada api", atau "don't look book just on the cover". Peribahasa-peribahasa tersebut menunjukkan bahwa hal-hal yang nyata dan dapat dicerap oleh indera penglihatan kerap kali perlu dijelaskan dan dipahami secara hati-hati, sehingga tidak terjadi kesalahan pemahaman oleh penerima atas pesan yang disampaikan oleh komunikan.

Kehati-hatian untuk mengambil sikap, termasuk dalam komunikasi visual, kiranya dapat mengacu pada kajian pemikiran filsafat, yakni etika. Frans Magnis Suseno (1989: 13-14) menyatakan bahwa etika adalah pemikiran kritis rasional dalam memecahkan masalah dan mencari nilai-nilai dasar kemanusiaan. Dalam filsafat, pemahaman tentang nilai dibedakan dalam tiga kategori, yakni: nilai kebaikan (moral), nilai kebenaran (episteme) dan nilai keindahan (aestetic). Dalam hal ini, kajian dibatasi pada aspek nilai kebenaran dalam proses komunikasi yang terwujud berkat penggunaan media. Pemikiran kritis diperlukan untuk melihat kesepadanan, apakah yang dilihat itu adalah memang demikian (sesuai dengan) yang maksud (isi pesan) komunikator. Pemikiran kritis rasional diperlukan, baik bagi komunikator maupun 
komunikan. Komunikator perlu mempertimbangkan secara matang media visual yang mampu menyampaikan pesan secara sepadan. Sementara itu, komunikan perlu mempertimbangkan secara rasional dan kritis, agar tidak terlena dengan visualisasi yang menarik media komunikasi.

Pengkajian tentang komunikasi visual dari perspektif etika secara komparatif dihubungkan dengan pemikiran para Filsuf Yunani kuno, karena mereka memberi contoh bagaimana memahami alam yang dicerap secara visual demi menemukan pengetahuan/pemahaman tentang segala yang ada. Cara berpikir yang sama, kiranya dapat dipergunakan untuk melihat secara kritis kesepadanan antara unsur visual yang dipergunakan sebagai media penyampaian pesan dengan isi pesan itu sendiri.

\section{METODOLOGI PENELITIAN}

Untuk menemukan prinsip-pinsip dasar komunikasi visual dari perspektif etika sebagai pemikiran filsafat, metode yang ditempuh biasa disebut dengan Metode Sistematis-Spekulatif (Bakker, 1990: 141). Metode sistematis-spekulatif sesungguhnya merupakan cara berpikir refleksif rasional yang didukung dengan metode interpretatif dan komparatif secara holistik filsafati. Dengan metode refleksi, hendak dicari adalah prinsip-pinsip yang mendasari guna memperoleh kebenaran yang mendasar, dan menemukan makna dari fokus kajian (Bakker dan Zubair, 1994: 15). Mengingat bahwa prinsip-prinsip dasar itu dicari dari kondisi nyata, maka diperlukan dukungan metode interpretatif filsofis. Ricouer (dalam Bakker dan Zubair, 1994: 42) berpandangan, bahwa fakta itu dibaca sebagai sebuah naskah. Kondisi faktual dipahami dan diinterpretasikan secara mendalam, beyond the fact. Sebagai misal, bahasa bukan sekedar bunyibunyi, melainkan sebagai proses komunikasi antara objek konkrit. Interpretasi itu bukan sebagai kegiatan manasuka, melainkan bertumpu pada kebenaran otentik.

Karena kajian itu berkenaan dengan interaksi atau interelasi yang saling memberi pengaruh, dilakukan pula metode komparasi, perbandingan. Melalui metode komparasi akan diperoleh pemahaman secara clear and distinct tentang kesamaan dan perbedaan. Dalam hal ini, fokus kajian akan tertuju pada dinamika komunikasi visual melalui pembandingan antara apa yang pernah dipikirkan oleh para filsuf, ketika memberi penafsiran dan menangkap gejala-gejalan visual sebagai sumber pengetahuan dengan dinamika proses komunikasi visual.

\section{HASIL DAN PEMBAHASAN}

Pencarian Kebenaran Dalam Pemahaman (Antara Yang Dilihat (Visual - Inderawi) Dan Yang Dipikirkan (Rasio)

Interpretasi atau pencarian makna yang bersifat rasional terhadap hal-hal yang ditangkap oleh indera penglihatan (visual) sesungguhnya sudah dimulai sejak jaman filsafat Yunani kuno, sekitar abad 6 sebelum Masehi. Tiga filsuf dari Miletos: Thales, Anaximander dan Anaximenes, berkeyakinan bahwa di balik segala perubahan alam, dunia sesungguhnya merupakan satu kesatuan yang teratur dan mempunyai suatu prinsip, asas yang bersifat tetap. Dengan mengandalkan pengamatan indera (visual), mereka mencari pemaham akan "arche-type", asas atau prinsip yang tetap sama di balik perubahan yang terus $m$ enerus (Bertens, 1981: 9). Yang menarik adalah bahwa, meski hal yang diamati itu adalah sama, tetapi para filsuf mempunyai perbedaan pemahaman tentang asas pertama alam semesta. Bagi Thales ( \pm 630 sebM), asas 
pertama itu adalah air. Sementara itu, Anaximander ( $\pm 600 \mathrm{SM})$ berpandangan, bahwa asas pertama itu adalah "yang tak terbatas" (to apeiron). Dan, menurut Anaximenes ( $\pm 550 \mathrm{SM}$ ) udara adalah unsur pertama dari segala sesuatu (Hamersma, 2018: 51). Bagi para filsuf mashab alam Miletos, berdasarkan pengamatan indera, istilah "alam" menunjuk pada sesuatu yang menyebabkan apa saja, mengambil sikap dan keadaan seperti yang tampak dalam kenyataan (Kattsoff, 2004: 256)

Seabad kemudian, setelah tiga Filsuf dari Miletos, Herakleitos $( \pm 470 \mathrm{SM})$ menggunakan metode berpikir yang serupa, ia menduga bahwa api merupakan asas pertama yang merupakan dasar segala sesuatu yang ada. Bagi Herakleitos, asas pertama itu tidak tunggal. Baginya, akal budi penangkap pemahaman bahwa kenyataan itu bersifat jamak dan terus-menerus berubah (pantha rei). Realitas bukanlah terdiri dari sejumlah sesuatu/benda, tetapi merupakan suatu proses dari penciptaan dan pemusnahan yang terus menerus. Herakleitos mengambil contoh pada esensi api, yang memberi gambaran tentang relasi antara yang tetap dan berubah. Semuanya berubah kecuali perubahan itu sendiri (everything changes but no changes itself).

Pencarian tentang asas pertama Herakleitos tersebut menyiratkan pemahamannya tentang adanya "logos". Dalam segala perubahan terdapat suatu logika yang mengatur perubahan, sehinggap perubahan tidak bersifat semena-mena.

Melanjutkan pemikiran filsuf alam, Pythagoras (sekitar 572-500 SM) tertarik pada kenyataan yang bersifat teratur. Pythagoras mengutarakan bahwa suatu penggambaran yang tepat tentang realita haruslah diungkapkan dengan bilangan dan dalam peristilahan rumus matematis. Baginya keteraturan hakekat alam dapat diukur sebagai bilangan (K. Bertens, 1981: 10). Karena bilangan sesungguhnya adalah unsur hakiki dari segala sesuatu, maka batas, bentuk, dan bilangan, menurut pemikiran Pythagoras adalah sesuatu yang sepadan. Pemahaman keteraturan matematis dan harmonis hanya dapat dilakukan dengan kemampuan akal manusia.

Penggunaan akal (rasio) dalam pemahaman akan hal-hal yang bersifat indera ditekankan kembali oleh Parmenides $( \pm$ 515-440 SM). Bahkan, Parmenides menekankan pentingnya rasio dalam pemahaman atas hal-hal inderawi. Jika indera dapat membuktikan perubahan, itu berarti indera menipu. Menurutnya, realitas adalah suatu keutuhan yang absolut. "Ada" yang penuh. Simpul dasarnya adalah : "yang ada itu ada" dan "yang tidak ada itu tidak ada". Bagi Parmenides, perubahan merupakan peralihan dari "yang tidak ada menjadi ada" dan/atau "yang ada menjadi tidak ada". Perubahan yang demikian tidak dapat dipikirkan, seperti halnya berpikir tentang yang tidak ada itu adalah kemustahilan rasio.

Cara berpikir Parmenides menampak perbedaan kontras atas pemikiran Herakleitos. Jika Herakleitos menawarkan cara pandang terhadap proses berdasarkan pengamatan visual, Parmenides menawarkan cara pengamatan rasio. Pengamatan rasio menunjukkan bahwa sesungguhnya tidak ada perubahan dan pergerakan. Karena itu, yang ada itu bersifat satu, tidak dapat dibagi-bagi. Hal kedua yang diwariskan Parmaneides pada filsuf sesudahnya adalah bahwa "engkau tak bisa menemukan pikiran tanpa sesuatu yang ada"; atau "apa yang dapat dipikirkan adalah apa yang ada dalam realitas". Pemahaman tentang "yang ada" oleh Parmenides menjadi embrio bagi cara berpikir yang mengandalkan kemampuan akal. Menurut Kees Bertens, Parmenides dapat disebut sebagai filsuf pertama yang meletakkan cara berpikir metafisika (Bertens, 1981: 10-11).

Pandangan Parmenides itu memunculkan "perlawanan" para filsuf masa itu yang tidak rela mengurbankan kesaksian pancaindera demi kecerdasan rasio. Demokritos ( \pm 420 SM) adalah 
salah satunya. la mengajukan jalan lain untuk menunjukkan pentingnya pengamatan inderawi. Bagi Demokritos, segala yang ada sebagai realitas sesungguhnya merupakan kumpulan unsur material kecil yang dapat dibagi hingga bagian terkecil yangtidak dapat dibagi lagi, yakni atomatom. Atom-atom yang begitu kecil tidak dapat ditangkap oleh indera penglihatan. Akan tetapi, atom itu selalu bergerak. Menurut kaum atomis, pergerakan atom yang terus-menerus membentuk realitas yang tampil bagi pancaindera. Pemikiran Demokritos, di samping mengembalikan pentingnya pengamatan inderawi, juga mendamai perbedaan pemikiran Herakleitos dan Parmenides.

\section{Kebenaran sebagai Tujuan Berpikir Demi Nilai Kemanusiaan}

Perbedaan pemikiran tentang realitas itu tunggal atau jamak, tetap atau berubah mendasari pencarian makna kebenaran. Dengan objek penelitian manusia, golongan Sofistik tidak menerima kebenaran yang bersifat tetap dan definitif. Kaum Sofis, misalnya, berpandangan bahwa kebenaran bersifat relatif. Tidak ada sesuatu pun yang benar, yang baik, yang bagus, "dalam dirinya". Sayangnya, bahwa pemikiran akan kebenaran yang demikian dimaksudkan untuk kemahiran dalam berpidato (Sutrisno dan Budiman. Ed., 1992: 11). Akibatnya, pemahaman akan relativitas pembenaran cenderung ke arah amoral, karena argumen tentang kebenaran semata untuk keuntungan diri sendiri, yakni kemahiran sebagai pengkotbah!! Mengkritik kaum Sofis, Protagoras, yang bagian dari mereka, berusaha menunjukkan pencarian kebenaran moral dengan menegaskan, bahwa "manusia adalah tolok ukur untuk segala-galanya" (homo mensura). Baginya, segala sesuatu adalah baik, bagus, atau benar hanya dalam korelasi dengan manusia.

Meneruskan pemikiran Protagoras, Sokrates $( \pm 470-399)$ menekankan perlunya penyelidikan yang berfokus pada manusia. Akan tetapi, ia tidak sepakat dengan Protagoras. Sokrates berpandangan bahwa "yang benar" dan "yang baik" harus diterima serta dijunjung tinggi oleh setiap manusia . sebagai nilai-nilai objektif. la berkeyakinan bahwa nilai kebenaran ada dalam diri setiap manusia, yang harus terus-menerus dicari. Cara pencarian yang dilakukan oleh Sokrates adalah dialog. Kepada setiap orang yang dijumpai, ia akan bertanya dan berdiskusi mengenai harapan dan maksud hidup baik dan benar. Arah dialog adalah dicapainya "pengetahuan" dan "kesadaran diri" yang terungkap atau dilahirkan kembali. Metode dialog itu dibandingkan dengan cara kerja ibunya sebagai seorang bidan, yakni maieutike tekhne (ketrampilan kebidanan). Bagi Sokrates dialog-dialog yang terarah mampu membantu seseorang supaya mampu melahirkan pengetahuan-pengetahuan (Sutrisno dan Budiman. Ed., 1992: 12). Hal ini adalah bukan semata-mata proses yang menyenangkan, melainkan penuh penderitaan, perjuangan, bahkan pengorbanan. Sokrates pun mengalami sendiri. Metode dialog yang ditawarkan, dianggap membahayakan negera. Akibatnya, hukuman matilah yang diterima, yakni diminta untuk memilih meminum cawan yang berisi racun, jika tetap berkeyakinan dan mempertahankan pendapatnya. Berhadapan dengan pilihan, hidup atau mati, Sokrates berdialog dengan teman-temannya. Dialog dimaksudkan untuk menemukan alasan-alasan yang mendasar mengenai kelayakan atau tidaknya dalam menerima hukuman atau melepaskan diri dari hukuman. Akhir dari dialog adalah bahwa Sokrates memilih mempertahankan keyakinannya, dan menjalani hukuman mati. Pilihan Sokrates kiranya harus dilihat sebagai keyakinan atas pengetahuan tentang hidup yang menjadi dasar pemahaman dan tolok ukur kesusilaan, hidup secara baik dan manusiawi. 


\section{Kebenaran Idea Lebih Pasti dari Kebenaran Inderawi}

Pencarian pengetahuan (episteme) Sokrates diteruskan oleh muridnya, Plato (427-347SM). Plato pun dikenal sebagai murid yang menulis gagasan-gagasan Sokrates. Maka, adalah wajar jika garis besar pemikiran tentang pengetahuan Plato sangat dipengaruhi oleh Sokrates. Pembeda sekaligus pengembangan pemikiran Plato adalah ketika ia mencari suatu asas pemikiran di antara ketegangan antara Parmenides dan Herakleitos. Setiap orang mengalami pertentangan antara pengetahuan murni dengan penangkapan atau pengetahuan inderawi. Bagi Plato, pengetahuan pada dasarnya ada dalam jati diri setiap orang sebagai sifat bawaan lahir. Pengetahuan itu bersifat murni. Pengetahuan yang demikian mengalahkan segala keragu-raguan yang diakibatkan oleh pelbagai penampilan dan pengalaman inderawi. Pengetahuan inderawi bersifat jamak, dan terus menerus berubah. Sementara, pengetahuan murni bersifat tetap dan satu.

Pemikiran Plato untuk menjawab ketegangan tersebut dijelaskan dalam mitologi tentang "the cave man".

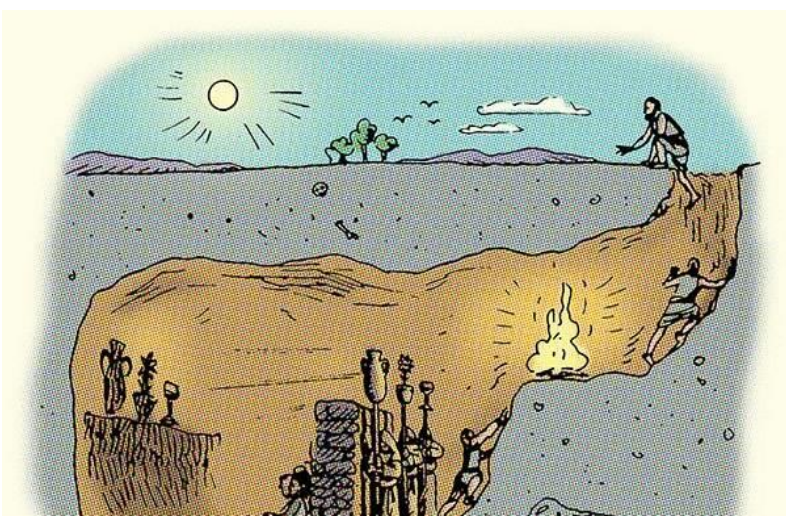

Gambar 1. The Cave Man

Sumber: Arsenio Wicaksono dalam geotimes

Pertama-tama kita bayangkan sekelompok orang yang ditawan sejak lahir. Orang-orang ini sejak kecil dirantai dalam gua. Tangan, kepala, dan kaki mereka diikat secara ketat, sedemikian hingga seumur hidup cuma dapat menatap dinding di depan mereka. Di belakang mereka terdapat api unggun besar. Apabila ada orang atau binatang lewat, maka bayangannya akan terpantul ke dinding di depan para tawanan. Setiap kali orang atau binatang itu bersuara, suaranya akan bergema sampai ke telinga para tawanan. Karena seumur hidup cuma melihat pantulan di dinding, para tawanan mengira bayangan dan gema itu sebagai "kenyataan sebenarnya". Poin utama Plato sampai di sini adalah bahwa manusia menyangka kenyataan berdasarkan apa yang mereka persepsi.

Melanjutkan cerita tersebut, Plato mengajukan pertanyaan: bagaimana kalau kita lepaskan satu orang dari tawanan tersebut? Karena seumur hidup dirantai, ia sulit bergerak. Matanya akan perih menatap cahaya terang dunia luar. Meskipun begitu, setelah beberapa waktu, dia akan beradaptasi. Matanya menyesuaikan diri; demikian pula dengan badannya. Dia menyadari bahwa ada kenyataan yang melampaui bayangan dalam gua. Dalam sekejap pengetahuannya bertambah ia tidak lagi menjadi "orang gua" yang sangat yakin akan pengamatannya sebagai yang benar Ketika melihat kembali ke dalam gua, orang ini akan menyadari bahwa kenyataan yang dipercaya selama ini salah. Jika orang yang sudah pernah bebas tersebut kembali ke dalam gua menemui teman-temannya, ia justru akan dikucilkan, karena pandangannya tentang kenyataan berbeda dengan mereka. Ada 
kemungkinan bahwa apabila hendak membebaskan teman-temannya ia akan dibenci karena menimbulkan rasa sakit yang luar biasa. Ada juga kemungkinan bahwa ia akan dipandang rendah. la tidak lagi pandai mengamati bayangan di dinding. Sementara di sisi lain: justru orang-orang dalam gua itu merasa diri sebagai yang mempunyai kebenaran.

Mitologi "the cave man" memberi petunjuk pemahaman Plato tentang realitas, yang dapat dibedakan dalam konsep dua "dunia". Dunia pertama adalah dunia "idea", yang terbuka bagi rasio. Dunia kedua adalah dunia "jasmani" yang terbuka bagi pancaindera. Dunia idea merupakan bersifat satu dan tetap. Ketika penciptaan, dunia idea membayang menjadi dunia jasmani, yang dapat ditangkap oleh indera. Dunia jasmani bersifat jamak dan terus-menerus berubah. Manusia, pada umumnya dapat disamakan dengan orang tahanan yang dibelenggu dalam gua. Mereka mengandaikan begitu saja, bahwa pengenalan indera itu memberi pemahaman tentang realitas yang sebenarnya.

Bagi Plato, manusia sesungguhnya mempunyai kemampuan mengenal kedua dunia, karena dalam diri manusia ada penggabungan dua dunia itu, yakni tubuh dan jiwa. Pada awalnya, sebelum lahir, jiwa ada terlebih dahulu ada bersama dan memandang idea-idea sempurna dan abadi, seperti idea kebaikan, kebenaran, keindahan, keadilan, juga idea manusia, hewan serta pohon. Karena kelahiran, jiwa dikurung dalam badan dan senantiasa rindu untuk memandang idea kembali. Berkat akal (ratio)nya manusia mampu untuk menghidupan kembali ingatan (anamnesis) akan dunia idea sebagai pengetahuan bawah sadar yang diharapkan akan dapat dilakukan ketika manusia melepaskan diri dari dunia. Untuk memahami kenyataan yang sesungguhnya, harus ada kemauan untuk mengatasi (mau keluar dari) dunia jasmani dan menumbuhkan hasrat untuk melihat dunia idea yang abadi. Kemampuan untuk menangkap ideaidea itu dapat terwujud dengan berpikir melalui konsep-konsep rasio, karena konsep rasio itu menunjuk kepada idea-idea yang mendasari realitas. Dengan cara demikian manusia mampu mempunyai pengetahuan yang bersifat umum dan objektif, tetap (Frans Magnis, 1996: 16).

Pengetahuan sebagai konsep rasio Plato oleh para pemikir disejajarkan dengan pengetahuan intuisi (Sutrisno dan Budiman. Ed., 1992: 12). Pengetahuan intuisi merupakan perwujudan atas ingatan akan suatu lapisan kesadaraan bawaan manusia. Melalui kesan dan pengamatan intuitif, manusia merasa bahwa ia sudah tahu, tanpa melakukan pengamatan.

Kebenaran Pemahaman Adalah Abstrasi Rasio Pengamatan Inderawi (Pengamatan Indera Dasar Pengetahuan)

ARISTOTELES (384-322) sepakat dengan pendapat Plato, gurunya, bahwa kebenaran itu bersifat umum dan tetap. Setiap manusia mendambakan pengetahuan yang paling sempurna. Akan tetapi sama sekali menolak pemikiran Plato tentang idea-idea sebagai sumber kebenaran. Bagi Aristoteles idea-idea itu tidak ada ada dalam kenyataan, tidak konkrit. Aristoteles berkeyakinan bahwa setiap pengetahuan akan segala hal dan bidang harus didasarkan pada hasil pengamatan indera.

Pengetahuan inderawi yang bersifat partikular diolah oleh akal (nous) melalui proses abstraksi menuju pengetahuan yang bersifat universal. Pengamatan inderawi memberi gambaran akan realitas yang terus bergerak. Secara spontan, akal mencari sumber pergerakan dan perubahan. Menurut Aristoteles, nous mampu memahami bahwa pergerakan tersebut sebagai rangkaian, deretan dinamika perubahan realitas. Dan, nous pada tahapan yang tertinggi 
mampu memahami ada-nya "yang menggerak tanpa digerakkan" (Sutrisno dan Budiman. Ed., 1992: 23).

Metode abstraksi diterapkan oleh Aristoles untuk memahami unsur-unsur materi yang dikenal dengan "Teori Forma-Materia (hilemorfisme). Dengan teori bentuk-materi, Aristoteles berpandangan, bahwa setiap benda (jasmani) terdiri dari dua unsur, yaitu bentuk dan materi. Sebagai misal: sebuah patung, terdiri bahan tertentu (batu atau kayu) dan bentuk tertentu (manusia atau kuda). Materi dan bentuk itu bukan bersifat dapat dilihat (visual), tetapi merupakan prinsip metafisis, yakni: harus diandaikan untuk memahami/mengerti benda-benda jasmani. Materi adalah prinsip yang sama sekali "terbuka", yang sama sekali tidak ditentukan. Itulah materi pertama (hyle prote). Materi itu adalah kemungkinan belaka (potentia) untuk menerima suatu bentuk (forma/morphe). Akan tetapi, pada kenyataannya, materi pertama itu selalu mempunyai salah satu bentuk, sebagai pinsip yang menentukan. Sebagai materi pertama, setiap benda bersifat konkrit (pohon ini); dan sekaligus karena bentuknya, suatu benda mempunyai kodrat tertentu (kodrat pohon, bukan binatang). Dengan pemahaman melalui abstraksi yang demikian, setiap setiap benda dapat dipahami dan dikenal oleh rasio sebagai benda konkrit. Kees Bertens, mengatakan, bahwa "bentuk-bentuk" dari Aristoleles itu boleh dianggap sebagai idea-idea yang sudah dipindah ke dalam benda-benda konkrit (K. Bertens, 1981: 16).

\section{Etika sebagai Pemikiran Kritis - pencarian nilai kebenaran (episteme)}

Secara historis, etika sebagai salah satu pemikiran filsafat lahir dan berkembang ketika terjadi kemerosotan moral dalam Kebudayaan Yunani 2.500 tahun silam (Suseno, 1989: 15). Yang menjadi pertanyaan mendasar adalah: bagaimana hakekat norma-norma dasar bagi manusia untuk bertindak. Manakah norma-norma yang dapat dipegang sebagai patokan tentang tanggung jawab dan kewajiban yang layak ditaati. Ketika norma-norma moral dipertanyakan, maka secara implisit juga dipertanyakan kaidah-kaidah pengetahuan (episteme) yang melatar belakangi pembentukan norma-norma. Pertanyaan-pertanyaan mendasar mengenai pengetahuan, berkisar tentang: asal-usul, sumber, susunan, metode dan kesahihan pengetahuan. Jika dirumuskan dalam kalimat pertanyaan: Apakah mengetahui itu? Darimana sumber pengetahuan? Bagaimana metode dalam memperoleh pengetahuan? Apakah pengetahuan itu benar atau sesat?

Sebagai kajian bersifat filsafati, jangan diharapkan bahwa akan ditemukan solusi yang bersifat teknis dan praktis. Sebab, pemikiran filsafat, termasuk etika dan epistemologi, memang dimaksudkan untuk memberi orientasi dan membuka keluasaan wawasan. Pemikiran filsafat adalah pencarian orientasi. Artinya, sebelum menentukan tindakan atau sebelum membuat norma-norma, diperlukan kepastian tentang statusquo, di mana, akan ke arah mana. Pelbagai faktor dipertimbangkan dan direncanakan. Tanpa orientasi, seseorang tidak tahu arah dan, bahkan, akan merasa terancam.

Kondisi yang demikian kiranya juga ada dalam bidang komunikasi. Permasalahan komunikasi, seperti, kesalahan pemahaman (misscomunicate), dapat disebabkan oleh baik dari sumbernya, media, penerima maupun kondisi yang melingkupi. Supaya, tidak permasalahan menjadi semakin besar, maka diperlukan pencarian orientasi sebelum memberi solusi. Kajian kali ini yang berfokus pada komunikasi visual, kiranya didasarkan usaha untuk membandingkan 
ketegangan mengenai perbedaan kesimpulan sebagai pengetahuan di antara para filsuf Yunani, meski sumber atau hal yang dikaji adalah sama, pengamatan indera.

\section{Komunikasi Visual Antara Isi dan Forma}

Mengenai makna komunikasi para ahli memberi definisi yang berbeda-beda. Carl.I.Hovland berpandangan, bahwa komunikasi adalah proses dimana seseorang memindahkan rangsangan yang berupa lambing-lambang atau kata-kata untuk mengubah tingkah laku orang lain (dalam Effendy, 1986: 5). Sementara itu, D Lawrence Kincaid mendefinisikan komunikasi sebagai suatu proses dimana dua orang atau lebih membentuk atau melakukan pertukaran informasi satu sama lainnya, yang pada gilirannya akan tiba pada saling pengertian yang mendalam (Cangara, 2007: 20). Sedangkan menurut Shannon dan Weaver, Komunikasi adalah bentuk interaksi manusia yang saling pengaruh mempengaruhi satu sama lainnya, sengaja atau tidak sengaja. Tidak terbatas pada bentuk komunikasi menggunakan bahasa verbal, tetapi juga dalam hal ekspresi muka, lukisan, seni dan teknologi (Cangara, 2007: 20). Benang merah yang dapat diambil atas definisi-definisi tersebut adalah bahwa komunikasi adalah suatu proses yang dinamis, ketika terjadi suatu transaksi secara verbal maupun non verbal pesan dari pengirim yang akan memberi pengaruh pada penerima baik personal maupun simbolik membutuhkan kode abstraksi bersama.

Komunikasi visual sebagai salah satu bentuk transaksi informasi non-verbal dapat diartikan sebagai proses transformasi (pengiriman) isi pesan dan/atau informasi yang dilakukan dengan mengandalkan (pencerapan/penerimaan) pencerapan indera penglihatan (visual) dari penerima. Saat ini peranan komunikasi yang diemban makin beragam: informasi umum, pendidikan (materi pelajaran dan ilmu pengetahuan, pelajaran interaktif pendidikan khusus), persuasi (periklanan, promosi, kampanye sosial) dan pemantapan identitas (logo, corporate identity, branding). Munculnya istilah "komunikasi visual" sebenarnya juga merupakan akibat dari makin meluasnya media yang dicakup dalam bidang komunikasi lewat bahasa visual: percetakan/grafika, televisi, web-design, film-video (vflog), fotografi dan sebagainya.

Penglihatan merupakan indera yang memberi informasi yang cepat dan lengkap, diperkirakan bahwa $70 \%$ hingga $80 \%$ dari pengetahuan manusia diperoleh melalui indera mata. Selain memanfaatkan mata sebagai sarana utama untuk memahami dunia, manusia menterjemahkan informasi yang diterima panca indera sebagai pemahaman indera visual. Akibatnya adalah dinamika komunikasi menjadi penyampaian dan penerimaan pesan melalui bahasa visual, yang dikenal dengan sebutan "komunikasi visual".

Media komunikasi visual mulai banyak digunakan, ketika penggunaan lambang-lambang, tanda-tanda, atau pun pelbagai desain grafis, bahkan fotografi dipandang cukup efektif dalam penyampaian pesan. Melalui pelbagai media visual tersebut, komunikator merasa lebih mampu mengekspresikan pesan. Komunikan pun kiranya dipandang mampu menangkap pesan yang dimaksudkan. Dampaknya adalah bahwa pemakaian visual untuk berkomunikasi semakin berkembang dan semakin baik. Mulai dari yang dua dimensi statis hingga tiga dimensi dinamis. Pada dasawarsa terakhir, pemanfaat media visual semakin jamak. Salah satunya yang bisa menjadi penanda peningkatan komunikasi visual adalah: emoticon, dan stiker di pelbagai aplikasi media sosial, seperti, Line, KakaoTalk, WhatsApp mau Telegrap. Sesuatu yang belum pernah terjadi pada sejarah komunikasi sebelumnya. 


\section{Manfaat Komunikasi Visual:}

Perkembangan pemanfaat media komunikasi visual kiranya didukung oleh asas manfaat dan kemudahan komunikasi visual. AT. Suryanto Dasep (2019: 1) menunjukkan manfaat komunikasi, yakni:

i. Informasi yang disampaikan jelas. Komunikasi visual merupakan proses penerusan infomasi yang disampaikan jelas, sehingga seorang komunikan secara mudah mampu memahami pesan yang disampaikan oleh komunikator.

ii. Menghemat konteks tulisan. Pesan yang disampaikan melalui suatu gambar atau visual ini berfungsi untuk menghemat konteks tulisan. Minimnya tulisan dalam komunikasi visual memudahkan komunikan memahami pesan yang disampaikan oleh komunikator.

iii. Menghemat tenaga. Visualisasi mengandalkan imajinasi yang sederhana agar komunikan juga mudah memahami pesan tersebut. Seorang komunikator tidak perlu menguras banyak tenaganya untuk menyalurkan komunikasi dalam bentuk komunikasi visual tersebut.

iv. Menghemat waktu. Komunikasi visual bermanfaat bagi seorang komunikator yang memiliki keterbatasan waktu. Visualisasi dapat merespon pesan yang disampaikan oleh komunikator secara dalam waktu singkat.

v. Menyalurkan imajinasi. Komunikasi visual bermanfaat sebagai penyalur imajinasi. Seorang komunikator akan menyampaikan pesan yang ada dipikirannya lebih mudah melalui media menggambar dan mudah dipahami oleh seorang komunikan.

vi. Meningkatkan kreativitas. Komunikasi visual yang mengutamakan gambar tentuna juga memuat nilai-nilai seni sebagai bentuk kreativitas komunikator ketika memberi kemasan pesan yang akan disampaikan kepada komunikan.

vii. Mudah diingat oleh penerima pesan. Komunikasi visual berperan penting dalam menyampaikan pesan karena komunikasi visual dianggap mudah untuk diingat oleh komunikan berkat aplikasi-aplikasinya. Pesan yang diaplikasikan melalui visual ini mudah diingat karena tertangkap jelas oleh mata.

viii. Menarik minat komunikan. Kreativitas dalam komunikasi visual ini berfungsi untuk menarik minat komunikan dalam menanggapi isi pesan yang disampaikan oleh komunikator. Ketika seorang komunikan tertarik dengan pesan yang disampaikan maka akan terjadi komunikasi yang sukses.

ix. Memberi pengaruh. Komunikasi visual, misalnya, fotografi sebuah kerusuhan dan kekerasan dapat berdampak untuk membangkitkan emosi penerima pesan. Dampaknya adalah mereka yang terpengaruh tanpa berpikir panjang akan melakukan tindakan serupa. Sebabnya, adalah bahwa seolah-olah ada presentasi kekerasan dalam media yang mengandung aspek estetik-destruktif yang mengundang ketertarikan (Haryatmoko, 2018: 121)

\section{Aspek Kognisi Media Visual}

Memang ada sementara ahli, yang berpandangan bahwa komunikasi visual bersifat praktis dan cenderung memberi pengaruh. Itu kiranya berlaku untuk lambang, tanda dan simbol yang sudah disepakati secara bersama. Akan tetapi, tidak dapat disangkal, bahwa media visual kadang 
kala menjadi problematis, ketika lambang, gambar itu belum disepakati. Dengan kata lain, perlu disadari bahwa media visual sesungguhnya bersifat sebagai persepsi yang terbuka, dan dapat bias makna dari fakta. Dapat diduga, bahwa penyampaian pesan secara visual menjadi multi tafsir. Sebagai misal komunikasi visual dalam bidang fotografi. Perbedaan kualitas fotografi yang ada dapat menimbulkan persepsi yang berbeda. Sebuah foto dapat saja menampilkan kemungkinan moral namun di sisi lain dapat memunculkan aneka penilaian. Bahkan, berdampak tidak menyenangkan. Contoh kasus lama adalah kisah Kevin Carter, seorang fotografer Jurnalis dari Afrika Selatan, pemenang Pulitzer pada tahun 1994.

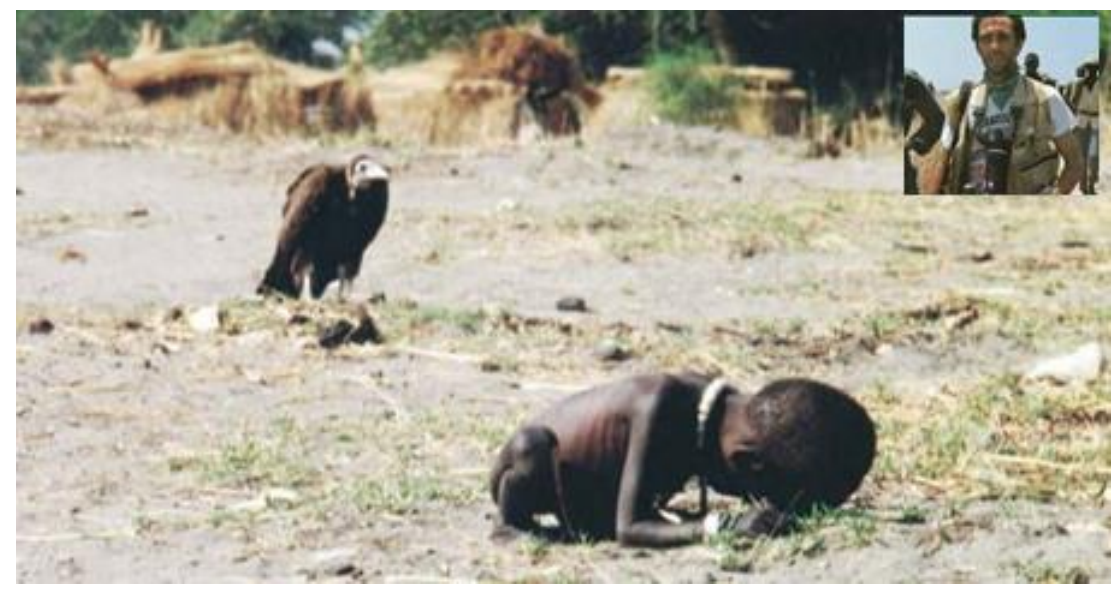

Gambar 2. Vulture and a Child by Kevin Carter, 1993 (http://100photos.time.com/)

(Kisah di balik fotografi pemenang Pulitzer 1994: Pada tahun 1993, ketika perang Sudan, saat itu orang tua dari anak malang ini sedang sibuk mengantri dan berebut untuk mendapatkan makanan dipusat pemberian bantuan makanan dari PBB sehingga terpaksa meninggalkannya. Di saat itulah Kevin Carter melihat seorang bocah kurus dan lemah sedang berusaha menyeret dirinya mendekati orang tuannya. Tampak seekor burung pemakan bangkai di belakangnya berkesan mengintainya. Foto yang menakjuban sekaligus miris ini mendapat anugerahi pulitzer prize setahun kemudian. Anugerah tersebut justru memicu cibiran pedas dan protes keras dari masyarakat: "ia tidak menolong anak itu dan malah menjadikannya sebagai objek foto". Muncul rasa penyesalan dan depresi Sang Fotografer. Carter kemudian melakukan bunuh diri beberapa saat setelah menerima penghargaan akibat tak tahan lagi menahan tekanan)

Demi menjamin peminimalan salah persepsi, penggunaan media visual perlu didukung aspek kognisi, baik dari komunikan maupun komunikator. Beberapa aspek kognisi yang perlu diperhatikan menurut Carolyn Bloomer (Purwanti, 2018: 1) adalah: ingatan, proyeksi, harapan, selektifitas, habituasi, saliance, dan disonansi (ketidaksesuaian).

i. Ingatan, merupakan aktivitas mental yang sangat menentukan persepsi visual secara akurat. Gambar kerap kali dipergunakan sebagai alat bantu mengingat peristiwaperistiwa atau benda-benda tertentu. Sebagai misal, penyelidikan peristiwa sebuah kecelakaan akan sangat dibantu dengan membuat gambar-gambar di tempat kejadian perkara untuk mengingat kronologi dan menemukan sebab-sebab kecelakaan. 
ii. Proyeksi, sebagai karakter kecenderungan pribadi yang dimiliki oleh setiap orang. Itulah sebabnya salah satu alasan bahwa psikolog menggunakan tes umum Rorschach inkblot, yakni untuk melihat ciri-ciri kepribadian oleh makna yang berasal dari bentuk-bentuk gambar yang dibuat.

iii. Harapan, yang muncul dalam imaginasi akan sebuah gambar akan memberi pengaruh entah kecewa atau senang, ketika berhadapan dengan kenyataan. Akronim "lebih indah dari warna aslinya" kiranya adalah ajak untuk berhati-hati atas gambar reklame sebuah produk. Memiliki prasangka harapan tentang bagaimana sebuah produk kiranya akan memperkecil kecewaan akibat kesalahan persepsi visual.

iv. Selektifitas, merupakan kemampuan manusia dalam menentukan pilihan. Dalam pencerapan visual, tidak jarang kemampuan ini melemah, sebab pikiran terfokus pada gambar yang ditangkap indera penglihatan. Akibatnya persepsi visual menjadi seperti intuisi instinktif.

v. Habituasi, muncul dari aktifitas rutin yang cenderung membuat jenuh dan disepelekan. Pencarian pengalaman baru jauh lebih menarik. Situasi yang demikian juga terdapat dalam pengalaman visual manusia. Kerap kali persepsi visual yang sudah menjadi kebiasaan ditinggalkan, dan mencari pengalaman visual yang baru. Jika demikian, perlu kehati-hatian supaya tidak terjadi culture shock.

vi. Salience, sebagai situasi bahwa ada hal yang dipandang sebagai prioritas, penting adalah lumrah pada setiap manusia. Dalam persepsi visual, skala prioritas akan membantu seseorang untuk mampu memahami makna pesan secara mendalam.

vii. Disonansi, kemampuan persepsi visual terganggu ketika berhadapan dengan banyak gambar atau aktifitas. Dampaknya adalah pemahaman akan makna gambar yang ada di hadapannya pun akan terganggu oleh gambar-gambar lain yang ada di sekitar.

\section{Pemahaman Komunikasi Visual Antara Isi dan Forma}

Pada masa sekarang, visualisasi yang mendukung proses pertukaran gagasan antara penyampai (komunikator) kepada penerima (komunikan) dianggap sebagai proses dinamika yang cukup penting. Bahkan ada kecenderungan bahwa cukup dengan melihat visual, maka langsung paham atas isi pesan. Sementara ahli berpandangan, bahwa media visual lebih mudah dalam membantu daya pencerapan dan ingatan. Sebabnya adalah bahwa kemampuan penalaran manusia lebih $80 \%$ berasal dari pencerapan indera penglihatan (Suryanto, 2019). Dipahami dan dirasakan pula, bahwa media visual lebih efektif. Komunikan lebih mudah paham, ketika ada ilustrasi. Dibandingkan dengan komunikasi konvensional, verbal, penggunaan media visual membuat proses komunikasi mampu melampaui batas-batas budaya, bahkan bahasa, serta latar belakang sosial. Efisiensi komunikasi visual terletak pada sifat universal pemaknaan gagasan yang dibawanya.

Justru atas dasar kondisi yang berkesan mudah tersebut, perlu kehatian-hatian, terutama kemungkinan munculnya kesalahpemahaman dalam dinamika komunikasi visual. Bahkan dapat terjadi bahwa sesungguhnya miss-persepsi memang disengaja, karena dorongan untuk mendapat pengaruh melalui rekayasa. Rekayasa visual disengaja untuk mengaburkan kesapadanan antara gagasan dan opini serta nilai sebagai fakta (Haryatmoko, 1981: 69). 
Untuk meminimalisir rekayasa visual, ada baiknya melihat dinamika komunikasi visual dengan mendasarkan pada ketegangan yang pernah terjadi antara Plato dan Aristoteles. Cara berpikir kedua tokoh besar dalam sejarah pemikiran filsafat, diharapkan mampu memberi wawasan mengenai kemungkinan perbedaan pemahaman dan sekaligus meminimalisirnya.

\section{Penerapan komunikasi visual ala "Idea-Idea" Plato}

Jika menurut Plato, bahwa yang utama dan pertama "ada" adalah Idea, maka dalam proses komunikasi, isi pesan dapat dianalogkan sebagai idea. Isi pesan sebagai gagasan awali berasal dari komunikator. Konsekuensi logisnya adalah bahwa komunikator perlu mencari media visual yang sepadan, yang sungguh mampu menjadi bayangan "idea” pesan. Sementara itu, komunikan, sebagai "the cave man", perlu kesadaran untuk lepas dari belenggu visual. Komunikan perlu membangun niat untuk memahami secara utuh isi pesan sesuai dengan sumber asalinya.

\section{Penerapan komunikasi visual ala "forma dan materia" Aristoteles}

Konsep hilemorfisme Aristoteles bahwa setiap benda terdiri dari forma dan materia, ketika diterapkan dalam proses komunikasi adalah: isi pesan berperan sebagai forma dan media adalah materia. Dari perspektif ini, komunikator yang baik akan memperhatikan, memilah, dan mencermati isi pesan. Memahami esensi isi pesan, dan jenisnya. Pencermatan ini diperlukan, supaya dapat dicarikan forma, media yang sepadan. Sementara itu, komunikan ala Aristoteles cukup menerima, melihat media hadir di hadapannya. Baginya, apa yang dilihat adalah demikian adanya.

Betapa pun tinggi idealisme komunikasi visual, entah ala Platois atau Aristotelian, logika pasar selalu memberi pengaruh. Mengacu pada pandangan Blumber, (Hariyatmoko 1981: 72-73) menunjukkan tiga akibat buruk komunikasi. Pertama, meredupnya media berkualitas dan maraknya media infotainment. Kedua, melemahnya rasa etis jurnalisme, karena tertutup oleh hedonisme. Dan ketiga, berkurangnya rasa keterikatan pada prinsip pelayanan publik dan norma objektif. Disadari atau tidak, komunikasi visual pun terbuka pada penyimpangan. Sebab-sebab penyimpangan komunikasi visual juga dapat dicari esensinya dengan rekaya model pemikiran Plato dan Aristoteles.

Rekayasa penyimpangan komunikasi visual ala Plato pada pihak komunikator secara singkat dapat dikatakan: komunikator kehilangan atau kehabisan gagasan. Akibatnya, sangat buruk, bahwa komunikator akan menyampaikan gagasan kosong, meski visualisasi yang ditampilkan begitu menarik. Sementara itu, komunikator merasa begitu yakin, bahwa apa yang dilihat adalah benar. Dinamika komunikasi visual yang demikian kiranya menjadi isu yang populer dalam aksi demo-aksi demo bayaran akhir-akhir ini.

Penyimpangan komunikasi visual ala Aristotelian kiranya akan menjadi hal yang menarik untuk perbincangan masyarakat. Situasi penyimpangannya adalah bahwa komunikator tidak memahami esensi gagasan yang disampaikan sejak awal. la tidak memahami kodrat, jenis pesan. Konsekuensi logisnya adalah media yang dipergunakan dapat diduga tidak sepadan. Sebagai misal, gambar pesan ucapan Hari Raya Keagamaan diterapkan sebagai pesan politik. Sementara itu, penikmat pesan visual tanpa berpikir panjang, akan segera bertindak atas persepsi visual yang diterima. 


\section{KESIMPULAN}

Dalam dinamika komunikasi, fakta menunjukkan adanya kecenderungan bahwa penerima (komunikan) merasa sudah cukup memahami isi pesan dan bahkan terpengaruh (sampai berbuat sesuatu), setelah hanya melihat (secara visual) medianya. Baginya, apa yang dilihat itu adalah memang demikian (sesuai dengan) yang maksud (isi pesan) komunikator. Padahal, ternyata, tidak demikian.

Untuk itu, diperlukan kehati-hatian, terutama bagi komunikator, dalam memilah dan memilih gagasan serta media visual yang akan diterapkan. Sementara itu, komunikan pun perlu bersikap selektif dan objektif ketika menerima persepsi visual. Berpikir dahulu sebelum bertindak karena hanya emosi.

\section{DAFTAR PUSTAKA}

Bakker, Anton, Dr., 1990. Metode-Metode Filsafat, Ghalia, Jakarta Bakker, Anton, Dr., Zubair, Achmad Charris, Drs. 1994. Metode Penelitian Filsafat, Kanisius, Yogjakarta Bertens, K., Dr. 1981. Ringkasan Sejaran Filsafat, Penerbitan Yayasan Kanisius, Yogyakarta Cangara, Hafied, Prof. Dr. H., M.Sc. 2007. Pengantar Ilmu Komunikasi, PT Raja Grafindo Persada, Jakarta Goldberg, Alvin A. dan Larson, Carl E., 2011, Komunikasi Kelompok - proses diskusi dan penerapannya, University of Denver, diterjemahkan oleh Koesdarini Soemiati dan Fary R. Yusuf, Penerbit Universitas Indonesia,

Effendy, Onong Uchjana, 1986. Dimensi Komunikasi, Penerbit Alumni, Bandung

Hamersma, Harry, Dr, 2018. Pintu Masuk ke Dunia Filsafat - Pustaka Filsafat, Penerbit Kanisius, Yogyakarta.

Haryatmoko, Dr., 2018. Etika Komunikasi- Manipulasi Media, Kekerasan, dan Pornografi, Penerbit PT Kanisius, Yogyakarta

Kattsoff, Louis O., 2004, Pengantar Filsafat, alih bahasa oleh Soejono Soemargono,Tiara Wacana, Yogyakarta

Suseno, F. Magnis, 1989. Etika Dasar - Masalah-masalah Pokok Moral, Penerbit Kanisius, Yogjakarta

Sutrisno, FX. Mudji dan Budiman, F., Ed.1992. Para Filsuf Penentu Gerak Zaman, Penerbit Kanisius, Yogjakarta

Dasep, Suryanto, AT., MM., Dr. 2019. Pentingnya Menguasai Komunikasi Visual, https://dasepsuryanto.com/2019/04/16/pentingnya-menguasai-komunikasi-visual/ , unduh 10 Agt 2020

Puput Purwanti, 2018. Teori Kognitif Dalam Komunikasi Visual Serta Pendekatannya, https://pakarkomunikasi.com/teori-kognitif-dalam-komunikasi-visual, unduh 14 Sept 2020 